\title{
Identifying the Extent of Using Methods for Developing Students' Creative Thinking by the Upper Primary Teachers in Public Schools in Tulkarem \& Irbid
}

\author{
Dr. Sameer Aowad Shdaifat ${ }^{1} \&$ Dr. Ja'far Wasfi Abu Saa ${ }^{2}$ \\ ${ }^{1}$ The vocational education department- Al-Huson University College- Al- Balqa' Applied University, Jordan \\ ${ }^{2}$ The technology education department, Faculty of art and educational sciences, Palestine Technical University- \\ Kadoorie, Palestine \\ Correspondence: Sameer Aowad Shdaifat, The vocational education department- Al-Huson University College- \\ Al- Balqa' Applied University. Email: dr.sameer_shdaifat@yahoo.com. Ja'far Wasfi Abu Saa', The technology \\ education department, Faculty of art and educational sciences, Palestine Technical University- Kadoorie. E-mail: \\ jaafarabusaa@yahoo.com
}

Received: November 1, 2019

Accepted: November 27, 2019 Online Published: November 30, 2019

doi:10.5539/mas.v13n12p93

URL: https://doi.org/10.5539/mas.v13n12p93

\begin{abstract}
The present study aimed to identify the extent of using methods for developing students' creative thinking by the upper primary teachers in public schools in Tulkarem \& Irbid. The researchers aimed to identify that from the students' perspective. In order to meet the study's goals, a questionnaire was designed. The questionnaire consists from 34 statements. It was designed for identifying the extent of using methods for developing students' creative thinking by the upper primary teachers. It sheds a light on several creative thinking development methods. The psychometric properties (reliability and validity) of the questionnaire were identified. A sample of students was selected. It consists from 442 female and male students. The sampled students were selected from the upper primary stage (i.e. the seventh, eighth and ninth grades). The sample was selected through using the random stratified sampling method in accordance with gender, grade, and city. The researchers concluded the following results:

1- The upper primary teachers highly use methods for developing students' creative thinking in the public schools in Tulkarem \& Irbid

2- The methods that are used the most by upper primary teachers for developing students' creative thinking in the public schools in Tulkarem \& Irbid are represented in the following:

- The teacher accepts the students' questions -that are not related to the subject -in the academic setting

- The teacher assigns enrichment activities to students in order to develop their creative thinking

- The teacher encourages students to come up with new ideas in the academic setting

- The teacher encourages students to show perseverance. He seeks encouraging students to engage in positive competitions

- The teacher introduces a new subject in an academic setting through asking questions that develop students' higher order thinking skills

*(These items are arranged descendingly)

3- The methods that are used the least by upper primary teachers for developing students' creative thinking in the public schools in Tulkarem \& Irbid are represented in the following:

- The teacher allocates opportunities to students equally in the academic setting in order to reach results

- The teacher runs the discussion in the classroom effectively

- The teacher uses the cooperative learning method
\end{abstract}


- The teacher asks probing questions which require thinking deeply

- The teacher displays the academic content in an unconventional manner

*(These items are arranged descendingly)

4- $\quad$ There isn't any statistically significant difference between the respondents' views which can be attributed to gender, grade, or city.

In the light of the aforementioned results, the researchers suggest several recommendations. For instance, they recommend providing teachers with training programs that enable them to use innovative methods when dealing with creative students. They also recommend conducting other studies that shed a light on the development of students' creative thinking with surveying the views of other categories of people.

Keywords: creative thinking, the upper primary teachers, Tulkarem, Irbid

\section{Introduction}

Creative thinking must be provided with special attention by educational systems. That must be done due to the need for creative thinking in the contemporary age. For instance, such thinking is needed today because individuals and societies today are facing many problems and challenges. In addition, it's needed because the intensity of the competition has been increasing rapidly. Furthermore, it's needed because it enables people to make scientific \& technological achievements. For instance, most of the scientific \& technological achievements of the $20^{\text {th }}$ century are made by people who think creatively.

Creative thinking is needed today due to the changes that have been occurring rapidly. It's needed because there are many national and global challenges. The most important challenges include knowledge explosion, technological development and openness to the world. The latter openness is attributed to the invention of advanced means for communication and transportation. Due to the invention of such means, the world has become a small village. In the light of such changes, each person became in need for creative thinking skills that enable him/her to solve problems (Hopkinson, 2009).

Development of creative thinking is the responsibility of all public institutions, especially the academic institutions, including universities. For instance, universities should provide students with courses that develop their creative thinking, and other types of thinking. Through such courses, students can develop their problem solving skills. Universities should provide all the resources for ensuring that these goals shall be met (Habib, 2006).

All individuals have creative capabilities. However, such capabilities differ from one person to another. These capabilities must be developed through training and acquiring knowledge. It should be noted that adopting conventional teaching methods shall hinder the development of these capabilities. It shall also hinder the development of individuals possessing excellent thinking skills and capable of innovating new things. In other words, adopting conventional teaching methods shall hinder the process of achieving comprehensive development during the $21^{\text {st }}$ century.

Today, faculty members are highly in need for using modern teaching methods that enrich students' information, develop students' cognitive skills and creativity and enable students to innovate things. Achieving that requires recruiting specialized faculty members who enable students to generate knowledge and carry out experiences. Such faculty members must provide students with suitable knowledge sources. They must arouse students' interest, and encourage them to think creatively. They must enable students to innovate. They must provide students' ideas with attention and enable students to use alternative methods for solving problems. They must display the thinking steps that are followed when solving a problem instead of displaying the result only. Recruiting such specialized faculty members shall encourage students to develop the thinking models and improve their capabilities to assess the learning outcomes effectively (Suk \& Sideny, 2006).

Many seminars and conferences indicate that faculty members play a significant role in developing students' creative thinking. Such seminars and conferences suggest that it's necessary to develop programs that enable faculty members to develop students' creative thinking (Al-Quds Open University, 2006).

\subsection{Statement of the Problem}

The problem of the present study is represented in seeking to identify the extent of using methods for developing students' creative thinking by the upper primary teachers in public schools in Tulkarem \& Irbid. The researchers aimed to identify that from the students' perspective. To be specific, the problem of the present study is represented in the following main question: 
Q.1. What is the extent of using methods for developing students' creative thinking by the upper primary teachers in public schools in Tulkarem \& Irbid from the perspective of students?

The following sub-questions are derived from the main question:

Q.2. Is there any statistically significant difference between the respondents' views which can be attributed to gender?

Q.3. Is there any statistically significant difference between the respondents' views which can be attributed to grade?

Q.4. Is there any statistically significant difference between the respondents' views which can be attributed to city?

\section{The Study's Theoretical Framework}

Promoting a sense of creativity within students and developing students' creative thinking are considered important goals that must be met by academic institutions. It can be noticed that academic institutions in developed countries provide much attention to meeting the latter goals. The provision of such attention enabled those countries to develop and advance in scientific and economic fields (Al-Odat, 2015)

\subsection{The Characteristics and Constituents of Creativity}

Creativity and creative thinking consist from several cognitive capabilities. Those capabilities were addressed by many studies in the fields of educational and psychology (Aqel, 2004; Al-Quds Open University, 2007; Narramore, 2011). The constituents of creativity and creative thinking include:

\subsubsection{First: Fluency}

This constituent is a quantitative constituent. It refers to the number of creative ideas that one can come up with for solving a problem. Creative ideas are characterized with being consistent with the requirements of the actual environment. Creative ideas don't include the ideas that aren't based on knowledge. For instance, they don't include the ones that are based on superstitions. The more ideas or answers that one can come up with during a specific time, the more fluent he/she is.

\subsubsection{Second: Flexibility}

This constituent is a qualitative constituent. It refers to the extent of variety of the creative ideas that one can provide. Flexibility refers to the extent of one's ability to change a specific situation or perspective.

\subsubsection{Third: Originality}

This constituent refers to one's ability to come up with a unique idea. In other words, this constituent refers to the extent of one's ability to come up with original ideas (i.e. ideas that are not frequently mentioned by the other group members). In other words, the lower the idea is mentioned by students, the more original the idea is. Therefore, the creative student is highly capable to propose ideas that are not common or frequently mentioned by others.

\subsubsection{Fourth: Problem Sensitivity}

This constituent refers to one's ability to come up with ideas with taking the details into consideration. It also refers to one's ability to adapt the ideas in a way that makes them applicable in other areas. In addition, it refers to one's ability to make contributions to a new idea. Being problem sensitive shall enable one to expand and develop a simple idea, scheme, or design.

\subsection{Barriers of Creativity}

Creativity is a word that is favorable to most people. It has special significance. It's very important to develop creativity and use it. Due to the significance of creativity, people desire to monopolize creative ideas and have control over them. However, many people are not creative. Therefore, many researchers seek identifying the reasons behind being not being creative. Such reasons include the following: (Swiatak, 2005; Al-Qathafy, 2002; S'ada, 2003):

1- Limiting the meaning of creativity to one definition:

That shall lead to having a limited perception for the concepts and things and their meaning. For instance, one may limit each English word to one meaning in Arabic language. Such limitation is considered as a major mistake. It shall hinder people from recognizing the beauty of Arabic and English languages. 
2- Not being capable to identify the actual problem:

Most people complain due to facing several problems in life. However, most of those people can't identify the main problem. Such identification can be made based on the characteristics of the problems

3- Having a limited experience:

That shall make one perceive any problem from a single perspective only. Such a perspective is often the first one that comes to mind. Therefore, in such a case, one shall make wrong assumptions.

4- Using the five senses incorrectly:

Carrying out things very quickly shall not provide one with adequate time to experience new things. In addition, it shall refrain one from using his senses correctly to solve problems. In such a case, the probabilities of falling a victim for deception and cheating acts shall increase (Ata-Allah, 2006).

5- Teaching through using conventional methods at schools:

That includes forcing students to sit still in their seats without being active participants. It also includes using the spoon-feeding method for teaching students. That shall hinder students from engaging in creative activities. It shall also hinder the development of students' creative capabilities (Kellmer, 2007).

\subsection{Development of creative thinking}

All of the psychologists agree that all people have creative capabilities. However, such capabilities differ from one person to another. If an academic institution wants to develop the students' creative capabilities, it must provide students with a classroom environment that makes them feel secure psychologically. In such an environment, the students' ideas and solutions mustn't be criticized nor mocked. In addition, the students' questions must be accepted. Students must be also encouraged to ask questions. In order to develop students' creative capabilities, the teacher must take the following measures (Al-Esawi, 2015; Khalifah, 2006):

- The teacher must stimulate students' imagination. That can be done through shedding a light on events and phenomena.

- The teacher must postpone the assessment outcome. In other words, the teacher shouldn't assess the students' outcomes instantly. The teacher's criticism must be based on reality. It must be also based on the displayed ideas.

- The teacher must enable students to be problem sensitive when dealing with (cognitive, social, and personal problems). That is because being problem sensitive is an essential requirement for solving problems.

- The teacher must develop students' curiosity. Curiosity in this context is represented in having the desire to know things in the aim of increasing knowledge. That shall make the students seek increasing their knowledge because they enjoy that.

- The teacher must promote the spirit of challenge among students when seeking to solve a problem

- The teacher must encourage students to adopt a skeptic approach. For instance, students must be skeptic about the validity of the solutions that have been proposed for solving a problem. That shall enable students to come up with new solutions.

- The teacher must display problems that are faced in reality. Such problems must be having an impact on one's life. The problems must be specific rather than general.

After the researchers reviewed the relevant studies, they found that there are many studies conducted about creative thinking. For instance, Al-Assaf (2013) aimed to identify attitudes of social studies teachers towards the development of creative thinking skills among the upper elementary students in Amman third Education Directorate. He aimed to identify that from the teachers' perspective. He aimed to identify whether there is any statistically significant difference between the respondents' attitudes which can be attributed to academic qualification or experience. He found that the teachers' attitudes are positive. He also found that there is a statistically significant difference between the respondents' attitudes which can be attributed to academic qualification. The latter difference is for the favor of the ones who hold postgraduate degrees. He also found that there isn't any statistically significant difference between the respondents' attitudes which can be attributed to experience.

Al-Shahab (2003) aimed to identify the role of teachers in developing students' creative thinking in public schools. He aimed to identify that from the perspective of academic supervisors and teachers the Sultanate of 
Oman. He found that the capabilities of academic supervisors to put effective supervising strategies are poor. He found that teachers do not have skills or methods that enable them to deal well with creative students.

Strom and Strom (2002) aimed to identify teachers' expectations in relation to students' creative thinking. It was found that there aren't strong correlation between the behaviors of creative students. It was found that teachers in five countries didn't provide attention to behavior. It was found that teachers encourages students to show obedient behaviors. Teachers also encouraged students to memorize the written academic material and everything that the teachers says. It was found that creative students ask many questions. Those students are capable to anticipate the occurrence of events. They are capable to handle risks. Teachers didn't provide attention to the behaviors that develop students' creative thinking. They provided attention to students' cognitive skills. Such skills shall reflect students' self-efficacy level.

\section{The Study's Approach}

The researchers adopted a descriptive analytical approach. This approach suits the study's nature and objective.

\subsection{The Study's Population and Sample}

The study's population involves all the students in the upper primary stage -(i.e. the seventh, eighth and ninth grades) - in Tulkarem \& Irbid. To be specific, the population involves 30656 female and male students who are enrolled in public schools in Tulkarem \& Irbid. A sample of students was selected through using the random stratified sampling method. It consists from 442 female and male students.

\subsection{The Study's Instrument}

The researchers used a questionnaire. This questionnaire consists from 34 statements. It sheds a light on several creative thinking development method. It covers two areas. The first area is represented in (encouragement and motivation). The first area involves 24 statements. The second area is represented in (questions and assessment). The second area involves 10 statements.

The five point-Likert scale was adopted. It involves several multiple choice response; strongly agree, agree, neutral, disagree, and strongly disagree. The scores of the latter scale is within the range of 1-5. The higher the score is, the higher the extent of using the creative thinking development method by the teacher. The lower the score is, the lower the extent of using the creative thinking development method by the teacher. In order to interpret the students' responses, the following criteria were used:

Less than 2.33: The creative thinking development method is used a little.

2.33-3.67: The creative thinking development method is moderately used.

More than 3.67: The creative thinking development method is highly used.

The gap between the criteria were identified through using the following equation:

The maximum value - the minimum value $/ 3+1=4 / 3=1.33$.

The questionnaire's validity was checked through passing the questionnaire to a panel of experts to provide their opinion. Those experts consists from 9 faculty members. They suggest that the questionnaire is valid. The researchers measured the reliability of the questionnaire through measuring the internal consistency. That was done through calculating the total value of the Cronbach Alpha coefficient. The latter value is 0.87 . It indicates that the instrument is highly reliable.

\subsection{Data Statistical Analysis}

In order to analyze the collected data statistically, the SPSS program was used. In addition, the following statistical analysis methods were used:

1- Arithmetic means, standard deviations and percentages were calculated

2- The two sample independent $t$-test was conducted

3- The one-way analysis of variance (ANOVA) was conducted

\section{Results and Discussion}

\subsection{First: The Results Related to the First Question}

Q.1.What is the extent of using methods for developing students' creative thinking by the upper primary teachers in public schools in Tulkarem \& Irbid from the perspective of students?

In order to answer the first question, means and standard deviations were calculated for each statement. These values are presented in table 1 below: 
Table 1. Means and standard deviations for identifying the extent of using methods for developing students' creative thinking from the perspective of students

\begin{tabular}{|c|c|c|c|c|c|c|}
\hline Rank & No. & Statement & $\begin{array}{l}\text { Arithmetic } \\
\text { mean }\end{array}$ & $\begin{array}{l}\text { Standard } \\
\text { deviation }\end{array}$ & Percentage & Level \\
\hline 1 & 3 & $\begin{array}{l}\text { The teacher accepts the students' } \\
\text { questions -that are not related to the } \\
\text { subject -in the academic setting }\end{array}$ & 4.39 & 0.53 & 87.83 & High \\
\hline 2 & 4 & $\begin{array}{c}\text { The teacher assigns enrichment activities } \\
\text { to students in order to develop their } \\
\text { creative thinking }\end{array}$ & 4.38 & 0.66 & 87.61 & High \\
\hline 3 & 21 & $\begin{array}{l}\text { The teacher encourages students to come } \\
\text { up with new ideas in the academic setting }\end{array}$ & 4.33 & 0.70 & 86.60 & High \\
\hline 4 & 20 & $\begin{array}{l}\text { The teacher encourages students to show } \\
\text { perseverance. He seeks encouraging } \\
\text { students to engage in positive } \\
\text { competition }\end{array}$ & 4.32 & 0.78 & 86.40 & High \\
\hline 5 & 10 & $\begin{array}{l}\text { The teacher introduces a new subject in } \\
\text { an academic setting through asking } \\
\text { questions that develop students' higher } \\
\text { order thinking skills }\end{array}$ & 4.30 & 0.71 & 86.00 & High \\
\hline 6 & 1 & $\begin{array}{l}\text { The teacher innovate new methods for } \\
\text { solving the existent problems }\end{array}$ & 4.29 & 0.58 & 85.80 & High \\
\hline 7 & 17 & $\begin{array}{l}\text { The teacher uses the group-discussion } \\
\text { method }\end{array}$ & 4.27 & 0.68 & 85.43 & High \\
\hline 8 & 5 & $\begin{array}{l}\text { The teacher displays strange ideas in } \\
\text { order to hold discussions about them }\end{array}$ & 4.25 & 0.61 & 85.00 & High \\
\hline 9 & 9 & $\begin{array}{l}\text { The teacher encourages students to } \\
\text { embrace the unusual ideas }\end{array}$ & 4.25 & 0.64 & 85.00 & High \\
\hline 10 & 14 & $\begin{array}{c}\text { The teacher displays information in a } \\
\text { manner that stimulates students' } \\
\text { skepticism }\end{array}$ & 4.23 & 0.59 & 84.57 & High \\
\hline 11 & 19 & $\begin{array}{c}\text { The teacher asks questions to introduce } \\
\text { other questions }\end{array}$ & 4.21 & 0.78 & 84.20 & High \\
\hline 12 & 12 & $\begin{array}{l}\text { The teacher asks questions about the } \\
\text { relationships between things }\end{array}$ & 4.20 & 0.71 & 84.00 & High \\
\hline 13 & 2 & $\begin{array}{l}\text { The teacher engages in a discussion with } \\
\text { the students in order to solve a specific } \\
\text { problem }\end{array}$ & 4.11 & 0.69 & 82.17 & High \\
\hline 14 & 16 & $\begin{array}{l}\text { The teacher asks questions to employ the } \\
\text { synthesis method }\end{array}$ & 4.10 & 0.73 & 82.00 & High \\
\hline 15 & 11 & $\begin{array}{l}\text { The teacher asks the student to provide } \\
\text { several solutions for a problem }\end{array}$ & 4.09 & 0.75 & 81.80 & High \\
\hline 16 & 6 & $\begin{array}{l}\text { The teacher extracts the solution from the } \\
\text { students' answers }\end{array}$ & 4.08 & 0.73 & 81.60 & High \\
\hline 17 & 13 & $\begin{array}{l}\text { The teacher asks questions that enable } \\
\text { students to differentiate between things }\end{array}$ & 4.08 & 0.60 & 81.52 & High \\
\hline 18 & 8 & $\begin{array}{l}\text { The teacher asks questions that stimulate } \\
\text { students' imagination }\end{array}$ & 4.04 & 0.85 & 80.82 & High \\
\hline 19 & 23 & The teacher asks open-ended questions & 3.99 & 0.83 & 79.78 & High \\
\hline
\end{tabular}




\begin{tabular}{|c|c|c|c|c|c|c|}
\hline 20 & 24 & $\begin{array}{l}\text { The teacher provides students with } \\
\text { incomplete solutions }\end{array}$ & 3.97 & 0.87 & 79.40 & High \\
\hline 21 & 15 & $\begin{array}{l}\text { The teacher interprets the meaning of } \\
\text { things in front of students }\end{array}$ & 3.86 & 0.87 & 77.17 & High \\
\hline 22 & 33 & $\begin{array}{c}\text { The teacher encourages students to } \\
\text { express their ideas }\end{array}$ & 3.62 & 0.97 & 72.40 & Moderate \\
\hline 23 & 25 & $\begin{array}{l}\text { The teacher listens to the students' ideas } \\
\text { with providing much attention }\end{array}$ & 3.45 & 1.02 & 69.00 & Moderate \\
\hline 24 & 32 & $\begin{array}{l}\text { The teacher enables students to reward } \\
\text { themselves when meeting a goal }\end{array}$ & 3.37 & 1.18 & 67.42 & Moderate \\
\hline 25 & 34 & $\begin{array}{l}\text { The teacher introduces a new lesson } \\
\text { through asking questions that help } \\
\text { students in retrieving previous } \\
\text { information }\end{array}$ & 3.17 & 0.70 & 63.40 & Moderate \\
\hline 26 & 28 & $\begin{array}{l}\text { The teacher seeks stimulating students' } \\
\text { thinking, rather than spoon-feeling them } \\
\text { with information }\end{array}$ & 3.12 & 1.00 & 62.40 & Moderate \\
\hline 27 & 7 & $\begin{array}{l}\text { The teacher encourages students to } \\
\text { complete the incomplete ideas }\end{array}$ & 3.06 & 0.92 & 61.20 & Moderate \\
\hline 28 & 18 & $\begin{array}{l}\text { The teacher encourages students to } \\
\text { research in an ongoing manner }\end{array}$ & 3.03 & 0.77 & 60.61 & Moderate \\
\hline 29 & 22 & $\begin{array}{l}\text { The teacher adjust his/her plan based on } \\
\text { the educational context }\end{array}$ & 3.03 & 1.10 & 60.60 & Moderate \\
\hline 30 & 29 & $\begin{array}{l}\text { The teacher displays the academic } \\
\text { content in an unconventional manner }\end{array}$ & 3.02 & 1.16 & 60.39 & Moderate \\
\hline 31 & 27 & $\begin{array}{l}\text { The teacher asks probing questions } \\
\text { which require thinking deeply }\end{array}$ & 3.01 & 1.10 & 60.20 & Moderate \\
\hline 32 & 31 & $\begin{array}{l}\text { The teacher uses the cooperative learning } \\
\text { method }\end{array}$ & 2.89 & 1.10 & 57.78 & Moderate \\
\hline 33 & 30 & $\begin{array}{l}\text { The teacher runs the discussion in the } \\
\text { classroom effectively }\end{array}$ & 2.62 & 1.16 & 52.39 & Moderate \\
\hline \multirow[t]{2}{*}{34} & 26 & $\begin{array}{c}\text { The teacher allocates opportunities to } \\
\text { students equally in the academic setting } \\
\text { in order to reach results }\end{array}$ & 2.60 & 1.10 & 52.00 & Moderate \\
\hline & & Total & 3.76 & 0.40 & 75.14 & High \\
\hline
\end{tabular}

Based on table 1, it can be concluded that the creative thinking development methods that are highly used by teachers are the ones mentioned in statements No. $(3,4,21,20,10,1,17,5,9,14,19,12,2,16,11,6,13,8,23,24$ and 15$)$ respectively. The percentages of those statements are within the range of $(87.83 \%-77.17 \%)$. As for the creative thinking development methods that are moderately used by teachers, they're the ones mentioned in statements No.

$(33,25,32,34,28,7,18,22,29,27,31,30$,and 26$)$. The percentages of those statements are within the range of (52\%$72.4 \%$ ). The overall percentage of statements is $75.14 \%$ which is high. That indicates that teachers highly use creative thinking development methods.

Based on table 1, the methods that are used the most by upper primary teachers for developing students' creative thinking in the public schools in Tulkarem \& Irbid are represented in the following:

- The teacher accepts the students' questions -that are not related to the subject -in the academic setting

- The teacher assigns enrichment activities to students in order to develop their creative thinking 
- The teacher encourages students to come up with new ideas in the academic setting

- The teacher encourages students to show perseverance. He seeks encouraging students to engage in positive competition

- The teacher introduces a new subject in an academic setting through asking questions that develop students' higher order thinking skills (These items are arranged descendingly)

Based on table 1, the methods that are used the least by upper primary teachers for developing students' creative thinking in the public schools in Tulkarem \& Irbid are represented in the following:

- The teacher allocates opportunities to students equally in the academic setting in order to reach results

- The teacher runs the discussion in the classroom effectively

- The teacher uses the cooperative learning method

- The teacher asks probing questions which require thinking deeply

- The teacher displays the academic content in an unconventional manner (These items are arranged descendingly).

\subsection{Second: The Results that are Related to the Second Question}

Q.2 Is there any statistically significant difference between the respondents' views which can be attributed to gender?

In order to answer the second question, means and standard deviations were calculated in accordance with gender. The two sample independent t-test was conducted to identify whether the difference between the means is statistically significant or not. The results of the latter test are presented in table 2 below:

Table 2. The results of the two sample independent t-test for identifying whether there is any statistically significant difference between the respondents' views which can be attributed to gender

\begin{tabular}{cccccc}
\hline Gender & Frequency & Mean & Std. deviation & $\begin{array}{c}\text { The calculated t } \\
\text { value }\end{array}$ & Sig. \\
\hline Male & 230 & 3.93 & 0.43 & 0.82 & 0.42 \\
Female & 212 & 3.99 & 0.34 & & \\
\hline
\end{tabular}

Based on table 2, it can be concluded that there isn't any statistically significant difference between the respondents' views which can be attributed to gender. That means that students' assessments for the extent of using creative thinking development methods by teachers don't vary from one gender to another.

\subsection{Third: The Results That are Related to the Second Question}

Q.3. Is there any statistically significant difference between the respondents' views which can be attributed to grade?

In order to answer the third question, means and standard deviations were calculated in accordance with grade. Those values are presented in table 5 below:

Table 3. Means and standard deviations for identifying the respondents' assessment for the extent of using creative thinking development methods by teachers in accordance with grade

\begin{tabular}{ccc}
\hline Grade & Mean & Standard deviation \\
\hline $7^{\text {th }}$ grade & 3.56 & 0.53 \\
$8^{\text {th }}$ grade & 3.63 & 0.64 \\
$9^{\text {th }}$ grade & 4.09 & 0.59 \\
Total & 3.76 & 0.40 \\
\hline
\end{tabular}


Based on table 3, it appears that there is a difference between the respondents' views which can be attributed to grade. In order to identify the statistical significance of those differences, the one-way analysis of variance (ANOVA) was conducted. The results of the latter analysis are presented in table (4) below:

Table 4. The results of the one-way analysis of variance (ANOVA) for identifying the statistical significance of the differences between the respondents' views which can be attributed to grade

\begin{tabular}{cccccc}
\hline $\begin{array}{c}\text { Source of } \\
\text { variance }\end{array}$ & $\begin{array}{c}\text { Sum of } \\
\text { squares }\end{array}$ & $\begin{array}{c}\text { Degree of } \\
\text { freedom }\end{array}$ & $\begin{array}{c}\text { average } \\
\text { deviation }\end{array}$ & $\begin{array}{c}\text { Calculated F } \\
\text { value }\end{array}$ & Sig. \\
\hline $\begin{array}{c}\text { between } \\
\text { groups }\end{array}$ & 0.056 & 2 & 0.028 & & \\
$\begin{array}{c}\text { Within groups } \\
\text { Total }\end{array}$ & 13.530 & 439 & 0.031 & 90.0 & 0.61 \\
\hline
\end{tabular}

Table 4 indicates that there isn't any statistically significant difference between the respondents' views which can be attributed to grade. That means that students' assessments for the extent of using creative thinking development methods by teachers don't vary from one grade to another.

\subsection{Fourth: Results related to the fourth question}

Q.4. Is there any statistically significant difference between the respondents' views which can be attributed to city?

In order to answer the fourth question, means and standard deviations were calculated in accordance with city. The two sample independent t-test was conducted to identify whether the difference between the means is statistically significant or not. The results of the latter test are presented in table 5 below:

Table 5. The results of the two sample independent t-test for identifying whether there is any statistically significant difference between the respondents' views which can be attributed to city

\begin{tabular}{ccccccccc}
\hline No. & Area & City & Frequency & Mean & $\begin{array}{c}\text { Std. } \\
\text { deviation }\end{array}$ & $\begin{array}{c}\text { Degrees } \\
\text { of } \\
\text { freedom }\end{array}$ & T value & Sig. \\
\hline \multirow{2}{*}{ Total } & $\begin{array}{c}\text { Total } \\
\text { score }\end{array}$ & Irbid & 278 & 3.86 & 0.46 & 168 & 1.93 & .060 \\
& & Tulkarem & 164 & 3.73 & 0.46 & & & \\
\hline
\end{tabular}

Table 5 indicates that there isn't any statistically significant difference between the respondents' views which can be attributed to city. That means that students' assessments for the extent of using creative thinking development methods by teachers don't vary from one city to another.

\section{Recommendations}

In the light of the aforementioned results, the researchers suggest the following recommendations:

First: Regarding schools, the researchers recommend:

1. Promoting the interaction between schools and local community. That shall participate in developing the knowledge, capabilities and expertise of students

2. Providing students with incentives that promote a sense of creativity within students

3. Providing educational resources at schools. That shall participate in promoting a sense of creativity within students

Second: Regarding students, the researchers recommend:

1. Encouraging students to show perseverance and have curiosity for exploring things

2. Encouraging students in an ongoing manner to reach the highest levels of creativity. 
3. Engaging students in decision making, activities and seminars. That shall participate in raising their academic position and developing their creativity

4. Enabling the students to interact positively with the environment in a manner that shall develop their creativity.

Third: Regarding teachers, the researchers recommend:

1. Developing teachers professionally in an ongoing manner

2. Engaging teachers in setting educational policies and regulations

3. Providing teachers with incentives. That shall participate in developing their creative capabilities

4. Providing teachers with training programs that enable them to use innovative methods when dealing with creative students

Fourth: Regarding future research, the researchers recommend:

5. Conducting other studies that shed a light on the development of students' creative thinking with surveying the views of other categories of people.

\section{References}

Al-Quds Open University. (2007). Creative thinking curriculum. Al-Quds Open University publications. The National Library. Palestine.

Al-Quds Open University. (2006). Elementary education curriculum. Al-Quds Open University publications. The National Library. Palestine.

Al-Shahab, Qais Hamad A'lawy (2003). The role of the teacher in developing the creative thinking of students in public schools from the perspective of academic supervisors and teachers in the Sultanate of Oman. Unpublished MA thesis. Yarmouk University. Irbid. Jordan.

Al-Assaf, Jamal (2013). Attitudes of Social Studies Teachers to the Development of Creative Thinking Skills among Students in the Basic Stage at Amman Third Education Directorate. Journal of the Islamic University for Educational and Psychological Studies, 21(1).p.269-292

Al-Esawi, Abed Al-Rahman (2015). Creativity-related psychology: A study for the development of creativity features. Beirut. Lebanon. Al-Nahda Al-Arabeya publication and distribution house. Beirut

Al-Odat, Ali Musleh (2015). The impact of a training program for teaching thinking skills on the development of creative thinking among a sample of kindergarten student in Jordan. Unpublished MA thesis. The University of Jordan. Amman. Jordan

Al-Qathafy, Ramadan Mohammad (2002). Taking care of creative gifted children. Alexandria. Al-Maktaba Al-Jame'eya.

Aqel, Fakher (2002). Creativity and education. Al-Elem Lelmalayeen publication and distribution house. Beirut

Ata-Allah, Salah Aldeen Farah (2006). For the development of the future: Features of the Ministry of Education's experiment of identifying gifted children in Khartoum. Khartoum. King Saud University

Habib, Abed Al-Salam (2006). Providing care to gifted students. Publications Agency. Jordan

Hopkinson's, D. (2009). Creativity in cooperative group setting. Journal of Research in Science Teaching, 22(1), 89-98. https://doi.org/10.1002/tea.3660220108

Kellmer, L. (2007). The education of gifted children. London Press.http:www.zajel.edu.ps/articles/artc-det.aspxald=21

Khalifah, Omar Haroun (2006). Identification of gifted students and the students of low academic achievement. The publications of the Regional Scientific Conference of Talents.

Narramore, R. (2011). Pricturing learning teacher research in words and images. Dissertation Abstracts, 53(11), 2827-A.

S'ada, Tareq (2003). The gifted Palestinian child in Ramallah. Ramallah. The Children Media Center.

Strom, D. \& Strom, S, (2002). Changing the rules: education for creative thinking. The Journal of creative behavior. 36(3). 183-199. https://doi.org/10.1002/j.2162-6057.2002.tb01063.x 
Suk, S. \& Sideny, M. (2006). A study of well-being and school satisfaction among academically talented students attending a Science High School in Korea. Gifted Child Quarterly, 50(2), 169-184. https://doi.org/10.1177/001698620605000207

Swiatek, M. (2005). An empirical investigation of the social coping strategies used gifted adolescents. Gifted Child Quarterly, 23(3), 291-297.

\section{Copyrights}

Copyright for this article is retained by the author(s), with first publication rights granted to the journal.

This is an open-access article distributed under the terms and conditions of the Creative Commons Attribution license (http://creativecommons.org/licenses/by/3.0/). 